\title{
Zoning and Trend Analysis of Temperatures for Fruit Crops in North-West India Using GIS
}

\author{
Mohan Singh ${ }^{1}$, Ram Niwas ${ }^{1}$, M.L. Khichar ${ }^{1}$ and A.K. Godara ${ }^{2 *}$ \\ ${ }^{1}$ Department of Agricultural Meteorology, CCS Haryana Agricultural University, Hisar, \\ Haryana, India \\ ${ }^{2}$ Department of Fruit Science, CCS Haryana Agricultural University, Hisar, Haryana, India \\ *Corresponding author
}

\begin{tabular}{|l|}
\hline Ke y w o r d s \\
North-west India, \\
Maximum and \\
minimum \\
temperatures, \\
Annual and \\
seasonal trend, Shift \\
in weather, \\
Temperatures zones \\
\hline Article Info \\
\hline $\begin{array}{l}\text { Accepted: } \\
\text { 26 December } 2017 \\
\text { Available Online: } \\
\text { 10 January } 2018\end{array}$ \\
\hline
\end{tabular}

\section{Introduction}

Temperature has a direct effect on all forms of life on earth, affecting a wide range of processes and activities ranging from human comfort and consequent energy supply and demand for heating and cooling, to crop and

\section{A B S T R A C T}

Study was conducted to quantify trend in temperatures, its variability and spatial distribution and its influence on fruit production in north-west India for this purpose more than 30 years data on maximum and minimum temperatures of twenty two different agrometeorological stations of Jammu \& Kashmir, Himachal Pradesh, Utrakhand, Punjab, Haryana, Chandigarh, Delhi, Uttar Pradesh and Rajasthan were used in this study. The temperature data was analyzed for computation of annual normal temperature and the coordinates were converted (into decimal system) for each meteorological station, for spatial analysis. Temperature trends for different meteorological stations in hills, plains of north-west India were evaluated using trend analysis. The map of north-west India was digitized and different temperature zones for maximum, minimum and mean temperature were delineated using GIS. Out of 22 stations, half of the stations showed a significant positive trend and another half negative trend in maximum temperature. A significant positive trend in minimum temperature of twenty stations but negative trend at Srinagar and Ranichauri was observed. Mean temperature showed significant positive trend at seventeen but negative at five stations. In north-west India as a whole a significant positive trend in annual maximum temperature $\left(0.1\right.$ to $3.0^{\circ} \mathrm{C} / 100$ years $)$, annual minimum temperature $\left(1.5\right.$ to $1.6^{\circ} \mathrm{C} / 100$ years $)$ and in mean temperature $\left(1.1\right.$ to $2.5^{\circ} \mathrm{C} / 100$ years $)$ was observed. The North-west India was divided into six zones of maximum temperature, seven zones of minimum temperature and five zones of mean temperature by taking a class interval of $2.5^{\circ} \mathrm{C}$. The study can be further refined by including the historical temperatures data of more and more meteorological stations located in the study area for better results.

domestic animals responses, the incidence of insects-pests, diseases and also rates of evapotranspiration. Temperature is a basic climatological parameter frequently used as an index to the energy status of an environment (De Jager and Schulze, 1977). The increased concentration of carbon dioxide $\left(\mathrm{CO}_{2}\right)$ and 
other trace GHG in the atmosphere, over the last century due to rapid industrialization and population pressure resulted in global warming. At present rate of $\mathrm{CO}_{2}$ emission is projected to be in the range of 500-1000 ppm by the end of this century, which will potentially increase global temperature by $1.8-5.8^{\circ} \mathrm{C}$ (IPCC, 2007). In case of $4^{\circ} \mathrm{C}$ rise in mercury level, there would be a $30 \%$ probability of temperature so high that even a moderate outdoor work cannot be carried out during the hottest month in north India. There will also be $40 \%$ chances that individual in north India will not be able to participate in competitive outdoor activities, if global temperature goes by average $1{ }^{\circ} \mathrm{C}$ (PTI, 2015).The Himalaya extending $3000 \mathrm{~km}$ in length and covering nearly 750,000 sq km of northern Pakistan, Nepal, Bhutan and Northwestern and North-eastern states of India forms wall which protect the lands area to its south from the scorching cold winds coming from Siberia and a source of eight major rivers of Asia and is known as "water tower of Asia" (IPCC, 2007; Xu et al., 2009).

The Himalayas region is one of the most complex young mountains systems in the world and is extremely vulnerable to global warming (Bandyophadhyay and Gyawali, 1994). Evidence of climate change in northwest India as in other parts of the world was reported (Kumar et al., 2015; Pathak et al., 2010; Sharma et al., 2009). Limited studies on temperature at few places in Himalayan region showed three times higher warming than the global average (Xu et al., 2009; Shrestha et al., 2012; IPCC, 2007). Some other studies also showed much higher warming in the last hundred years (Du et al., 2004 and IPCC, 2007). Though Himalayas are vulnerable to climate change (Xu et al., 2009) and undergoing rapid environmental change (Bawa et al., 2010), there is no systematic analysis of climate change in this region (Sharma et al., 2009; Shrestha et al., 2012).
First and foremost research gap identified by Sharma et al., (2009) is the lack of knowledge on rate climate change at regional and local levels. Lack of daily weather data for more number of years and locations in the region is the main constraint for assessment of climate change and related extreme climatic events. So, the present study was panned to evaluate temperature trend in relation to fruit production in north-west India.

\section{Materials and Methods}

\section{Location of the study area}

Twenty two meteorological stations, Srinagar, Jammu (Jammu \& Kashmir), Manali, Shimla, Palampur, Solan (Himachal Pradesh), Ranichauri (Utrakhand), Ludhiana, Bathinda Patiala (Punjab) Chandigarh, Ambala, Karnal, Rohtak, Sirsa, Hisar, Bawal, Narnaul (Haryana) Delhi, Sriganganagar, Jaipur (Rajasthan) Saharanpur and in Uttar Pradesh located in north-west India were selected for the study. The experimental site was the northwest India (Map 1) which approximately is located between $26^{\circ} 40^{\prime}$ to $37^{0} 10^{\prime} \mathrm{N}$ latitude and between $72^{\circ} 50^{\prime}$ and $81^{\circ} 00^{\prime}$ E longitudes. The altitude of area varies between 200 to 8600 meters above mean sea level. Total area of the site is approximately 5 lakh square $\mathrm{km}$ out of this 1000 thousand hectare is covered under the fruit crops. It has geographic features like the cold desert, the coldest place on the earth (Akbar et al., 2013), the Higher Himalaya, the Middle Himalaya, the Lower Himalaya, the Shiwalik hills, semi desert sandy plain and the Aravali range and the hot Thar Desert. The latitude, longitude and altitude of all the stations, along with their climatic types are given in Table 1. Based on the altitude, the study area was divided hills $>1000$ meters (Srinagar, Manali, Shimla, Palampur, Solan and Ranichauri) and Plains (Jammu, Chandigarh, Ambala, Saharanpur, Delhi, Karnal, Patiala, Ludhiana, Rohtak, 
Bathinda, Hisar, Sirsa, Bawal, Narnaul, Ganganagar and Jaipur) $<1000$ meters. Similarly, the whole year was divided into two seasons namely effective growing season (EGS) and dormant season (DS) for regional and seasonal of data analysis. EGS for hills was considered from April to October and for plains from March to October, similarly DS for hills was considered from November to March and for plains from December to February, respectively.

\section{Data collected}

Monthly maximum and minimum temperature data of twenty two locations, viz., Manali, Shimla, Solan, Chandigarh, Ambala, Saharanpur, Delhi, Karnal, Patiala, Ludhiana, Rohtak, Bathinda, Hisar, Narnaul, Ganganagar and Jaipur for the year from 1980 to 2014 and at Srinagar, Palampur, Ranichauri, Ranichauri, Sirsa, Bawal for the year from 1985 to 2014, respectively were used for the study. These data were collected from India Meteorological Department), Central Research Institutes for Dry Land Agriculture (CRIDA), revenue departments state agricultural universities (SAUs), Regional Research Stations (RRS), Regional Horticultural Research Stations etc.

\section{Calculation of statistical measures}

Annual means of maximum, minimum and mean temperature were calculated by averaging over 365 days of each year. Similarly, seasonal and monthly means of temperatures were calculated by averaging over the days of respective season or month of each year. Keeping the growth behaviour of fruit crops in mind the two seasons considered in this paper: effective growing season (EGS) and dormant season (DS) for regional and seasonal comparison of data analysis. EGS for hills was considered from April to October and for plains from March to October, similarly DS for hills was considered from November to
March and for plains from December to February, respectively. The monthly means of temperature data were further averaged over time periods (decadal) 1985-1994, 1995-2004, 2005-2014 at each station. Statistical measures like normal (long period average) standard deviation, coefficient of variation, slope, standard error, t-values, and significance (probability) and regression coefficient were computed using 'OP Stat' software from daily temperature data of more than 30 years at each station. Annual, seasonal and decadal statistical measures were computed at hills, plains and whole of the north-west India.

\section{Analysis of data}

Trend in temperatures were assessed through simple linear regression between weather parameters (Annual, monthly, seasonal and decadal) at hills, plains and north-west India. Significance of regression (or trends) was assessed through $F$-test and $P$-levels. Student's t-test was used to test the significance of difference between decadal means of weather parameters. Descriptive statistics like, arithmetic mean, standard deviation, coefficient of vitiation, t-values, probability (p) in maximum and minimum temperatures were worked out for all the twenty two stations, hills, plains and whole of the north-west India. Percent share of a station in normal temperature (PST) was worked out by dividing the normal temperature of a station by the summation of all the normals and multiplied by hundred as:

PST $=$ Normal temperature of the station x100/ $\sum$ Normal temperatures.

\section{Shift analysis}

The monthly means of temperatures data were averaged over three time periods (decadal) 1985-1994 (D1), 1995-2004 (D2), 2005-2014 (D3) at each station, hills, plains and north-west 
India and D1 and D3 were compared to know if there were any shifts in temperatures over these time period.

\section{Spatial analysis}

Maps depicting spatial variation in annual and seasonal temperature were prepared using ArcMap 10.1 GIS software by taking followed steps:

The hard copy of the map of the study area was digitized and shape file was created.

North-west India polygon shape file was selected.

The latitude-longitude values of each point were find out and converted to degree-decimal format to enter in GIS.

The coverage file (point) was then generated from the location data in ArcMap (10.1) GIS software.

The thermal and LGP data entered as attribute table and attached/joined to the point file already generated.

Then the point file was interpolated by GIS tools and converted to raster format by krigging/radial basis interpolation function.

\section{Results and Discussion}

\section{Normal maximum temperature}

The share in long period average (normal) of maximum and minimum temperatures worked out on annual \& seasonal basis for each station was given in Tables 2a, 2b, 3a and 3b. Among the six stations comes under hills (Srinagar, Manali, Shimla, Palampur, Solan and Ranichauri) the monthly mean maximum temperature was lowest at Srinagar $\left(19.4^{\circ} \mathrm{C}\right)$ followed by Shimla $\left(19.6^{\circ} \mathrm{C}\right)$ and Ranichauri $\left(19.7^{\circ} \mathrm{C}\right)$ and highest at Solan $\left(25.4^{\circ} \mathrm{C}\right)$ and followed by Palampur $\left(23.7^{\circ} \mathrm{C}\right)$ with PST of $3.11,3.14,3.15,4.07$ and $3.79 \%$, respectively (Table 2a). The mean minimum temperature was lowest at Srinagar $\left(6.7^{\circ} \mathrm{C}\right)$ followed by Ranichauri $\left(10.2^{\circ} \mathrm{C}\right)$ and Manali $\left(10.4^{\circ} \mathrm{C}\right)$, highest was at Palampur $\left(13.5^{\circ} \mathrm{C}\right)$ followed by Solan $\left(11.4^{\circ} \mathrm{C}\right)$ with PST of $1.99,3.02,3.08$, 4.00 and $3.38 \%$, respectively (Table 3a).The mean normal temperature was lowest at Srinagar $\left(13.1^{\circ} \mathrm{C}\right)$ followed by Ranichauri $\left(14.9^{\circ} \mathrm{C}\right)$ and Shimla $\left(15.3^{\circ} \mathrm{C}\right)$, highest was at Palampur $\left(18.6^{\circ} \mathrm{C}\right)$ followed by Solan $\left(18.4^{\circ} \mathrm{C}\right)$ with PST of $2.73,3.10,3.19,3.87$ and $3.83 \%$, respectively.

In plains the monthly mean maximum temperature was lowest at Ludhiana $\left(29.7^{\circ} \mathrm{C}\right)$ followed by Jammu $\left(29.9^{\circ} \mathrm{C}\right)$ and Karnal $\left(29.9^{\circ} \mathrm{C}\right)$ and highest at Ganganagar $\left(32.9^{\circ} \mathrm{C}\right)$ followed by Jaipur $\left(32.1^{\circ} \mathrm{C}\right)$ with PST of 4.75 , $4.79,4.79,5.27$ and 5.14, respectively (Table 2a). The monthly mean minimum temperature was lowest at Saharanpur $\left(14.6^{\circ} \mathrm{C}\right)$ followed by Hisar $\left(16.3^{\circ} \mathrm{C}\right)$ and Jammu $\left(16.7^{\circ} \mathrm{C}\right)$ and highest at Jaipur $\left(19.2{ }^{\circ} \mathrm{C}\right)$ followed by Ganganagar $\left(16.9^{\circ} \mathrm{C}\right)$ with PST of $4.33,4.83$, 4.95, 5.69 and 5.34, respectively (Table 3a).

\section{Seasonal maximum temperature}

The PST of mean maximum temperature was 26.49, 38.37and $35.15 \%$ for annual, 27.90, 37.31 and 34.79 for effective growing season, $27.53,37.63$ and $34.84 \%$ for dormant season at hills, plain and north-west India, respectively (Table 2a). The corresponding value of PST for minimum temperature was 24.65, 39.77 and 35.58 for annual, 27.41, 37.82 and 34.87 (Table 3a). The annual maximum temperature was most variable at Shimla (CV 5.6\%) followed by Manali (CV $4.7 \%)$ and Srinagar (CV 4.6\%) and comparably less variable at the remaining stations (CV of 1.1 to $3.6 \%$ ). During the effective growing season the average 
maximum temperature was between $25.6^{\circ} \mathrm{C}$ and $34.8^{\circ} \mathrm{C}$ in the study area (Table $2 \mathrm{a}$ ). The coefficient of variation was highest $(9 \%)$ for Manali followed by Shimla (4.5\%) and Srinagar $(4.2 \%)$. The coefficient for variation varied from 1 to 4 per cent for rest of stations being lowest for Chandigarh (1.55) and Karnal (1.6\%). The normal maximum temperature for dormant season varied from $10-15^{\circ} \mathrm{C}$ for Srinagar, Manali, Shimla, Ranichauri with coefficient of variation 7 to $12.2 \%$, from 15 $20^{\circ} \mathrm{C}$ for Palampur, Ludhiana and from 20$25^{\circ} \mathrm{C}$ for Solan, Jammu, Chandigarh, Ambala, Saharanpur, Delhi, Karnal, Patiala, Rohtak, Bathinda, Hisar, Sirsa, Bawal, Narnaul, Ganganagar, Jaipur with coefficient of variation less than 7\% (Table 2a). The standard error for maximum temperature was almost at par for annual as well as on seasonal basis but was somewhat higher during the dormant season (Table 2b).

The annual maximum temperature for hills (includes Srinagar, Manali, Shimla, Palampur, Solan and Ranichauri) was $21.4^{\circ} \mathrm{C} \pm 0.84$, for plains (includes rest 16 stations) was $31.0^{\circ} \mathrm{C} \pm$ 0.65 and for the whole of north-west India it was $28.4^{\circ} \mathrm{C} \pm 0.70$. The coefficient of variation was 4.0, 2.1 and $2.6 \%$ for hills, plains and north-west India, respectively. The standard error and t-value were higher for the hills as compared to the plains but the significance (p) was higher for plains $(3.85 \%)$ as compared to hills and the north-west India (Table 2b). During effective growing season the maximum temperature for hills was $25.5^{\circ} \mathrm{C}$, for plains $34.1^{\circ} \mathrm{C}$ and for north-west India it was $31.8^{\circ} \mathrm{C}$ with the coefficient of variation $4.2 \%, 2.1 \%$ and $2.6 \%$ for hills, plains and north-west India, respectively.

\section{Normal minimum temperature}

For annual normal minimum temperature the coefficient of variation was found highest (16.0\%) for Manali followed by Srinagar
(7.8\%) and Ranichauri (6.6\%) and lowest for Saharanpur (1.8\%) followed by Patiala (1.8\%). Its value for Sirsa, Shimla and Solan varied from 5.3 to 5.7 for Narnaul, Bawal and Jammu varied from 4.2 to 4.5 per cent and for the remaining stations Saharanpur, Patiala, Karnal, Delhi, Bathinda, Chandigarh, Ganganagar, Ludhiana, Ambala, Hisar, Rohtak and Jaipur it was between 1.8 and 3.7 per cent (Table 3a). During the effective growing season the normal minimum temperature was between $20.1^{\circ} \mathrm{C}$ and $22.3^{\circ} \mathrm{C}$ for Chandigarh, Ambala, Delhi, Karnal, Patiala, Ludhiana Bathinda, Sirsa, Bawal, Narnaul, Ganganagar and Jaipur and varied between 11.5 and $19.7^{\circ} \mathrm{C}$ for Srinagar Manali, Shimla, Palampur, Solan, Ranichauri, Jammu and Saharanpur. The slope was negative for Srinagar, Shimla, Palampur and Ranichauri and positive for remaining eighteen stations (Table 3a). Significance level (p) of $\mathrm{R}^{2}$ was at 0.970 for Saharanpur and it was less than 0.602 for all the remaining twenty one stations (Table 3b).The normal minimum temperature during dormant season varied from $0-5^{\circ} \mathrm{C}$ for Srinagar, Manali, Solan and Ranichauri and from $5-10^{\circ} \mathrm{C}$ for Shimla, Palampur, Jammu, Chandigarh, Ambala, Saharanpur, Delhi, Karnal, Patiala, Ludhiana, Rohtak, Bathinda, Hisar, Sirsa, Bawal, Narnaul, Ganganagar and Jaipur. The normal value of annual minimum temperature was $10.6^{\circ} \mathrm{C} \pm 0.73$ for the hills $17.1^{\circ} \mathrm{C} \pm 0.57$ for plains and for whole of north-west India it was $15.3^{\circ} \mathrm{C} \pm 0.62$. The coefficient of variation was $7.3 \%, 3.3 \%$ and $4.4 \%$ for hills, plains and for north-west India, respectively (Table 3a). The standard error was higher for hills as compared to plains and significance (p) was higher in hills than plains and whole of north-west India (Table 3b). During effective growing season the normal minimum temperature for the hills was $14.8^{\circ} \mathrm{C}$ for plains was $20.5^{\circ} \mathrm{C}$ and for north-west India it was $18.9^{\circ} \mathrm{C}$ with coefficient of variation of $6.2 \%, 3.3 \%$ and $4.0 \%$, respectively. 


\section{Trends in temperatures}

Out of twenty two stations, half showed the decreasing trend and another half increasing trend in maximum temperature. It was increasing with a rate of $0.0-10.5^{\circ} \mathrm{C}$ per 100 years at Srinagar, Manali, Shimla, Palampur, Solan, Ranichauri, Saharanpur, Ludhiana, Rohtak, Ganganagar and Jaipur whereas it was decreasing at the remaining eleven stations with a very low rate of $0.0-2^{\circ} \mathrm{C}$ per 100 years (Table 2a). The slope was positive for hills (0.030), plains (0.001) and north-west India (0.009) and was higher for hills compared to plains and the north-west India. The maximum temperature was increasing with $3.0^{\circ} \mathrm{C} / 100$ years in hills, $0.1^{\circ} \mathrm{C} / 100$ years in plains and $0.9^{\circ} \mathrm{C}$ per 100 years in north-west India. This reflects the regional warming as reported by IPCC $5^{\text {th }}$ reports (IPCC, 2014). Similar trend was observed by Negiet al., (2012) and Jain and Kumar (2012).
The slope of minimum temperature was positive for all the stations except Srinagar, Palampur and Ranichauri where it was negative. The warming rate of $12.1^{\circ} \mathrm{C}$ per 100 year was observed at Manali which was highest and the lowest rate was observed at Shimla. The slope was positive for hills (0.016), plains $(0.015)$ and 0.016 for northwest India (Table 3a).

The minimum temperature showed an increasing trend for hills, plains and northwest India which was also reported by Jangra \& Singh (2011). The increasing rate was $1.6^{\circ} \mathrm{C} / 100$ years for hills, $1.5^{\circ} \mathrm{C} / 100$ years for plains and $1.6^{\circ} \mathrm{C}$ per 100 years for north-west India. An increase in minimum temperatures $\left(0.07^{\circ} \mathrm{C} /\right.$ year $)$, decrease in maximum temperatures $\left(0.02^{\circ} \mathrm{C} /\right.$ year $)$ also reported by Kaurand Hundal (2006) in Ludhiana, Punjab and by Vinod (2015) for different meteorological stations in Haryana.

Table.1 Geographical information of different meteorological stations

\begin{tabular}{|l|l|l|l|l|l|}
\hline S. No. & Station & Latitude & Longitude & Altitude $(\mathbf{m})$ & Division \\
\hline $\mathbf{1}$ & Srinagar & 34.09 & 74.79 & 1600 & \\
\hline $\mathbf{2}$ & Manali & 32.27 & 77.17 & 2050 & Hills \\
\hline $\mathbf{3}$ & Shimla & 31.11 & 77.17 & 2397 & \\
\hline $\mathbf{4}$ & Palampur & 32.12 & 76.53 & 1219 & \\
\hline $\mathbf{5}$ & Solan & 30.92 & 77.12 & 1600 & \\
\hline $\mathbf{6}$ & Ranichauri & 30.06 & 78.99 & 1950 & \\
\hline $\mathbf{7}$ & Jammu & 32.73 & 74.87 & 327 & \\
\hline $\mathbf{8}$ & Chandigarh & 30.75 & 76.78 & 321 & \\
\hline $\mathbf{9}$ & Ambala & 30.38 & 76.78 & 264 & \\
\hline $\mathbf{1 0}$ & Saharanpur & 29.96 & 77.54 & 268 & \\
\hline $\mathbf{1 1}$ & Delhi & 28.62 & 77.21 & 216 & \\
\hline $\mathbf{1 2}$ & Karnal & 29.69 & 76.98 & 245 & \\
\hline $\mathbf{1 3}$ & Patiala & 30.34 & 76.38 & 350 & \\
\hline $\mathbf{1 4}$ & Ludhiana & 30.91 & 75.85 & 244 & \\
\hline $\mathbf{1 5}$ & Rohtak & 28.89 & 76.57 & 220 & \\
\hline $\mathbf{1 6}$ & Bathinda & 30.23 & 74.95 & 201 & \\
\hline $\mathbf{1 7}$ & Hisar & 29.15 & 75.71 & 215 & \\
\hline $\mathbf{1 8}$ & Sirsa & 29.53 & 75.01 & 205 & \\
\hline $\mathbf{1 9}$ & Bawal & 28.08 & 76.58 & 266 & \\
\hline $\mathbf{2 0}$ & Narnaul & 28.01 & 76.01 & 308 & \\
\hline $\mathbf{2 1}$ & Ganganagar & 29.92 & 73.88 & 178 & \\
\hline $\mathbf{2 2}$ & Jaipur & 26.91 & 75.81 & 431 & \\
\hline
\end{tabular}


Table.2a Statistical measures for annual maximum temperatureat different stations

\begin{tabular}{|c|c|c|c|c|c|c|c|c|c|c|c|c|}
\hline \multirow[t]{2}{*}{ Stations } & \multicolumn{3}{|c|}{ PST (\%) } & \multicolumn{3}{|c|}{ Standard deviation } & \multicolumn{3}{|c|}{ CV (\%) } & \multicolumn{3}{|c|}{ Slope (rate) } \\
\hline & Annual & EGS & DS & Annual & EGS & DS & Annual & EGS & DS & Annual & EGS & DS \\
\hline Srinagar & 3.11 & 3.66 & 2.45 & 0.88 & 1.1 & 1.3 & 4.55 & 4.2 & 12.2 & 0.022 & 0.02 & 0.05 \\
\hline Manali & 3.31 & 3.61 & 3.29 & 0.98 & 2.1 & 2.1 & 4.72 & 9.0 & 9.0 & 0.025 & 0.01 & 0.04 \\
\hline Shimla & 3.14 & 3.29 & 3.38 & 1.10 & 1.0 & 1.4 & 5.60 & 4.5 & 9.7 & 0.100 & 0.09 & 0.12 \\
\hline Palampur & 3.79 & 3.89 & 4.27 & 0.52 & 0.7 & 1.0 & 2.20 & 2.6 & 5.5 & 0.070 & 0.03 & 0.12 \\
\hline Solan & 4.07 & 4.11 & 4.70 & 0.90 & 0.9 & 1.6 & 3.55 & 3.3 & 7.6 & 0.105 & 0.06 & 0.17 \\
\hline Ranichauri & 3.15 & 3.31 & 3.36 & 0.64 & 0.6 & 1.1 & 3.24 & 2.5 & 7.2 & 0.005 & 0.00 & 0.01 \\
\hline Jammu & 4.79 & 4.72 & 4.63 & 0.77 & 1.0 & 1.1 & 2.57 & 2.9 & 5.4 & -0.027 & -0.02 & -0.06 \\
\hline Chandigarh & 4.85 & 4.75 & 4.90 & 0.55 & 0.5 & 1.1 & 1.80 & 1.6 & 4.9 & -0.001 & 0.01 & -0.03 \\
\hline Ambala & 4.82 & 4.75 & 4.72 & 0.61 & 0.6 & 1.0 & 2.01 & 1.7 & 4.9 & -0.005 & 0.01 & -0.04 \\
\hline Saharanpur & 4.87 & 4.72 & 5.00 & 0.34 & 0.6 & 0.9 & 1.13 & 1.8 & 4.1 & 0.060 & 0.07 & 0.04 \\
\hline Delhi & 4.96 & 4.88 & 4.95 & 0.53 & 0.6 & 1.0 & 1.72 & 1.8 & 4.6 & -0.017 & -0.01 & -0.05 \\
\hline Karnal & 4.79 & 4.72 & 4.70 & 0.55 & 0.5 & 0.9 & 1.85 & 1.6 & 4.4 & -0.002 & 0.01 & -0.03 \\
\hline Patiala & 4.87 & 4.74 & 4.75 & 0.73 & 0.6 & 0.7 & 2.40 & 1.8 & 3.5 & -0.009 & -0.01 & -0.01 \\
\hline Ludhiana & 4.75 & 4.71 & 4.52 & 0.56 & 0.7 & 0.8 & 1.90 & 2.0 & 4.2 & 0.013 & 0.02 & 0.00 \\
\hline Rohtak & 5.09 & 4.98 & 5.15 & 0.60 & 0.7 & 0.9 & 1.89 & 1.9 & 4.0 & 0.004 & 0.01 & -0.01 \\
\hline Bathinda & 5.03 & 4.98 & 4.90 & 0.56 & 0.8 & 0.9 & 1.78 & 2.3 & 4.3 & -0.024 & -0.02 & -0.18 \\
\hline Hisar & 5.03 & 4.97 & 4.88 & 0.72 & 0.7 & 0.9 & 2.28 & 2.1 & 4.3 & -0.011 & -0.01 & -0.03 \\
\hline Sirsa & 5.01 & 4.97 & 4.81 & 0.67 & 0.7 & 1.2 & 2.13 & 2.1 & 5.6 & -0.007 & 0.01 & -0.06 \\
\hline Bawal & 5.09 & 5.04 & 4.86 & 0.69 & 0.8 & 1.1 & 2.16 & 2.2 & 5.3 & -0.003 & -0.01 & 0.00 \\
\hline Narnaul & 5.09 & 4.98 & 5.13 & 0.98 & 1.0 & 1.2 & 3.09 & 2.9 & 5.5 & -0.023 & -0.02 & -0.04 \\
\hline Ganganagar & 5.27 & 5.21 & 5.13 & 0.80 & 0.9 & 0.9 & 2.42 & 2.5 & 4.1 & 0.032 & 0.05 & -0.01 \\
\hline Jaipur & 5.14 & 4.98 & 5.50 & 0.81 & 0.9 & 1.0 & 2.51 & 2.5 & 4.3 & 0.024 & 0.02 & 0.02 \\
\hline Hills & 26.49 & 27.90 & 27.53 & 0.84 & 1.1 & 1.4 & 3.98 & 4.2 & 9.0 & 0.030 & 0.03 & 0.04 \\
\hline Plains & 38.37 & 37.31 & 37.63 & 0.65 & 0.7 & 1.0 & 2.10 & 2.1 & 4.6 & 0.001 & 0.01 & -0.02 \\
\hline NW India & 35.15 & 34.79 & 34.84 & 0.70 & 0.8 & 1.1 & 2.61 & 2.6 & 5.5 & 0.009 & 0.01 & -0.003 \\
\hline
\end{tabular}

PST: Percent share of a station in normal temperature 
Table.2b Statistical measures for annual maximum temperature at different stations

\begin{tabular}{|c|c|c|c|c|c|c|c|c|c|c|c|c|}
\hline \multirow[t]{2}{*}{ Stations } & \multicolumn{3}{|c|}{ S. E. } & \multicolumn{3}{|c|}{ ' $t$ ' } & \multicolumn{3}{|c|}{ 'p' } & \multicolumn{3}{|c|}{$\mathbf{R}^{2}$} \\
\hline & Annual & EGS & DS & Annual & EGS & DS & Annual & EGS & DS & Annual & EGS & DS \\
\hline Srinagar & 0.023 & 0.02 & 0.03 & 0.96 & 0.70 & 2.02 & 0.327 & 0.474 & 0.045 & 0.032 & 0.017 & 0.128 \\
\hline Manali & 0.016 & 0.02 & 0.02 & 1.53 & 0.70 & 2.10 & 0.135 & 0.489 & 0.043 & 0.064 & 0.015 & 0.118 \\
\hline Shimla & 0.011 & 0.01 & 0.02 & 9.52 & 8.63 & 6.94 & 0.000 & 0.000 & 0.000 & 0.745 & 0.706 & 0.609 \\
\hline Palampur & 0.030 & 0.03 & 0.04 & 2.34 & 0.99 & 3.17 & 0.023 & 0.309 & 0.003 & 0.255 & 0.058 & 0.385 \\
\hline Solan & 0.019 & 0.02 & 0.03 & 5.61 & 2.63 & 6.76 & 0.000 & 0.011 & 0.000 & 0.570 & 0.223 & 0.656 \\
\hline Ranichauri & 0.015 & 0.01 & 0.02 & 0.34 & 0.05 & 0.52 & 0.730 & 0.960 & 0.592 & 0.004 & 0.000 & 0.010 \\
\hline Jammu & 0.020 & 0.02 & 0.02 & -1.39 & -0.76 & -2.47 & 0.175 & 0.453 & 0.020 & 0.067 & 0.022 & 0.190 \\
\hline Chandigarh & 0.010 & 0.01 & 0.02 & -0.11 & 0.54 & -1.40 & 0.912 & 0.595 & 0.171 & 0.000 & 0.009 & 0.059 \\
\hline Ambala & 0.010 & 0.01 & 0.02 & -0.54 & 0.88 & -2.63 & 0.595 & 0.384 & 0.013 & 0.008 & 0.022 & 0.165 \\
\hline Saharanpur & 0.069 & 0.06 & 0.10 & 0.87 & 1.07 & 0.36 & 0.357 & 0.262 & 0.695 & 0.087 & 0.125 & 0.016 \\
\hline Delhi & 0.011 & 0.01 & 0.02 & -1.55 & -0.70 & -2.39 & 0.132 & 0.492 & 0.023 & 0.076 & 0.016 & 0.164 \\
\hline Karnal & 0.006 & 0.01 & 0.01 & -0.34 & 0.71 & -2.62 & 0.737 & 0.480 & 0.012 & 0.003 & 0.012 & 0.144 \\
\hline Patiala & 0.011 & 0.01 & 0.02 & -0.81 & -0.64 & -0.93 & 0.423 & 0.528 & 0.363 & 0.022 & 0.014 & 0.029 \\
\hline Ludhiana & 0.014 & 0.01 & 0.02 & 0.91 & 1.49 & -0.15 & 0.370 & 0.147 & 0.885 & 0.030 & 0.076 & 0.001 \\
\hline Rohtak & 0.008 & 0.01 & 0.01 & 0.54 & 1.14 & -0.76 & 0.594 & 0.260 & 0.453 & 0.007 & 0.032 & 0.015 \\
\hline Bathinda & 0.014 & 0.02 & 0.08 & -1.75 & -0.90 & -2.30 & 0.081 & 0.359 & 0.024 & 0.098 & 0.028 & 0.158 \\
\hline Hisar & 0.007 & 0.01 & 0.01 & -1.54 & -0.76 & -2.58 & 0.131 & 0.453 & 0.013 & 0.052 & 0.013 & 0.134 \\
\hline Sirsa & 0.015 & 0.02 & 0.02 & -0.45 & 0.47 & -2.46 & 0.644 & 0.628 & 0.016 & 0.007 & 0.008 & 0.178 \\
\hline Bawal & 0.014 & 0.02 & 0.02 & -0.24 & -0.32 & -0.08 & 0.809 & 0.752 & 0.940 & 0.002 & 0.003 & 0.000 \\
\hline Narnaul & 0.014 & 0.02 & 0.02 & -1.69 & -1.10 & -2.58 & 0.091 & 0.267 & 0.012 & 0.073 & 0.032 & 0.156 \\
\hline Ganganagar & 0.014 & 0.02 & 0.02 & 2.25 & 2.99 & -0.49 & 0.031 & 0.005 & 0.626 & 0.141 & 0.223 & 0.008 \\
\hline Jaipur & 0.013 & 0.01 & 0.02 & 1.82 & 1.68 & 1.34 & 0.077 & 0.103 & 0.189 & 0.092 & 0.079 & 0.052 \\
\hline Hills & 0.019 & 0.02 & 0.02 & 3.38 & 2.28 & 3.59 & 0.203 & 0.374 & 0.114 & 0.257 & 0.170 & 0.318 \\
\hline Plains & 0.016 & 0.02 & 0.03 & 0.25 & 0.36 & -1.38 & 0.385 & 0.386 & 0.278 & 0.001 & 0.045 & 0.092 \\
\hline NW India & 0.017 & 0.02 & 0.03 & 0.74 & 0.89 & -0.03 & 0.335 & 0.382 & 0.234 & 0.046 & 0.079 & 0.153 \\
\hline
\end{tabular}


Table.3a Statistical measures for annual minimum temperatureat different stations

\begin{tabular}{|c|c|c|c|c|c|c|c|c|c|c|c|c|}
\hline \multirow[t]{2}{*}{ Stations } & \multicolumn{3}{|c|}{ PST (\%) } & \multicolumn{3}{|c|}{ Standard deviation } & \multicolumn{3}{|c|}{ CV (\%) } & \multicolumn{3}{|c|}{ Slope (rate) } \\
\hline & Annual & EGS & DS & Annual & EGS & DS & Annual & EGS & DS & Annual & EGS & DS \\
\hline Srinagar & 1.99 & 2.76 & 0.01 & 0.52 & 0.8 & 0.61 & 7.75 & 6.7 & 8945 & -0.034 & -0.04 & 0.00 \\
\hline Manali & 3.08 & 3.56 & 3.10 & 1.67 & 1.7 & 1.7 & 15.98 & 11.7 & 38.8 & 0.121 & 0.12 & 0.12 \\
\hline Shimla & 3.29 & 3.53 & 4.25 & 0.59 & 0.6 & 0.8 & 5.36 & 4.1 & 13.2 & 0.000 & -0.01 & 0.01 \\
\hline Palampur & 4.00 & 4.23 & 5.54 & 0.30 & 0.5 & 0.5 & 2.25 & 2.8 & 6.8 & -0.008 & -0.02 & 0.00 \\
\hline Solan & 3.38 & 3.92 & 3.31 & 0.65 & 1.0 & 0.8 & 5.69 & 6.2 & 16.7 & 0.025 & 0.02 & 0.04 \\
\hline Ranichauri & 3.02 & 3.36 & 3.24 & 0.67 & 0.9 & 0.9 & 6.60 & 6.4 & 19.4 & -0.034 & -0.04 & -0.03 \\
\hline Jammu & 4.95 & 4.73 & 5.47 & 0.76 & 1.1 & 1.0 & 4.52 & 0.5 & 1.3 & 0.036 & 0.06 & -0.02 \\
\hline Chandigarh & 5.22 & 4.97 & 5.83 & 0.53 & 0.6 & 0.7 & 3.04 & 2.9 & 8.2 & 0.022 & 0.03 & 0.00 \\
\hline Ambala & 5.13 & 4.93 & 5.47 & 0.55 & 0.6 & 0.8 & 3.19 & 3.1 & 10.5 & 0.013 & 0.01 & 0.01 \\
\hline Saharanpur & 4.33 & 4.30 & 3.24 & 0.26 & 0.4 & 0.8 & 1.80 & 2.5 & 17.4 & 0.023 & 0.00 & 0.09 \\
\hline Delhi & 5.22 & 5.05 & 5.33 & 0.47 & 0.5 & 0.6 & 2.68 & 2.6 & 8.4 & 0.013 & 0.02 & -0.01 \\
\hline Karnal & 5.04 & 4.83 & 5.26 & 0.39 & 0.4 & 0.7 & 2.28 & 2.0 & 9.2 & 0.012 & 0.01 & 0.01 \\
\hline Patiala & 5.16 & 4.95 & 5.40 & 0.32 & 0.4 & 0.6 & 1.82 & 2.1 & 8.6 & 0.013 & 0.01 & 0.02 \\
\hline Ludhiana & 4.98 & 4.85 & 4.90 & 0.53 & 0.6 & 0.8 & 3.12 & 2.9 & 11.2 & 0.049 & 0.06 & 0.04 \\
\hline Rohtak & 5.31 & 5.07 & 5.54 & 0.66 & 0.8 & 0.8 & 3.71 & 3.7 & 11.1 & 0.015 & 0.01 & 0.03 \\
\hline Bathinda & 5.01 & 4.88 & 4.46 & 0.48 & 0.9 & 0.9 & 2.82 & 4.3 & 13.9 & 0.000 & 0.02 & 0.04 \\
\hline Hisar & 4.83 & 4.76 & 4.10 & 0.60 & 0.6 & 0.8 & 3.65 & 3.3 & 14.9 & 0.013 & 0.01 & 0.01 \\
\hline Sirsa & 5.16 & 5.02 & 5.04 & 0.93 & 1.1 & 1.0 & 5.34 & 5.3 & 13.9 & 0.069 & 0.07 & 0.05 \\
\hline Bawal & 4.86 & 4.83 & 3.74 & 0.70 & 0.7 & 1.1 & 4.28 & 3.6 & 21.0 & 0.027 & 0.03 & 0.03 \\
\hline Narnaul & 5.01 & 4.90 & 4.54 & 0.71 & 0.8 & 0.8 & 4.23 & 3.9 & 12.2 & 0.008 & 0.01 & 0.00 \\
\hline Ganganagar & 5.34 & 5.19 & 5.18 & 0.55 & 0.7 & 0.7 & 3.09 & 3.0 & 9.5 & 0.022 & 0.03 & 0.01 \\
\hline Jaipur & 5.69 & 5.36 & 7.05 & 0.75 & 0.8 & 0.8 & 3.91 & 3.7 & 8.3 & 0.028 & 0.03 & 0.01 \\
\hline Hills & 24.65 & 27.31 & 25.28 & 0.73 & 0.9 & 0.9 & 7.27 & 6.2 & 19.4 & 0.016 & 0.01 & 0.02 \\
\hline Plains & 39.77 & 37.82 & 39.33 & 0.57 & 0.7 & 0.8 & 3.34 & 3.3 & 11.5 & 0.015 & 0.02 & 0.01 \\
\hline NW India & 35.58 & 34.87 & 35.39 & 0.62 & 0.8 & 0.8 & 4.42 & 4.0 & 13.0 & 0.016 & 0.02 & 0.01 \\
\hline
\end{tabular}


Table.3b Statistical measures for annual minimum temperature at different stations

\begin{tabular}{|c|c|c|c|c|c|c|c|c|c|c|c|c|}
\hline \multirow[t]{2}{*}{ Stations } & \multicolumn{3}{|c|}{ S. E. } & \multicolumn{3}{|c|}{ 't' } & \multicolumn{3}{|c|}{ 'p' } & \multicolumn{3}{|c|}{$\mathbf{R}^{2}$} \\
\hline & Annual & EGS & DS & Annual & EGS & DS & Annual & EGS & DS & Annual & EGS & DS \\
\hline Srinagar & 0.015 & 0.02 & 0.01 & -2.27 & -2.81 & -0.25 & 0.025 & 0.007 & 0.799 & 0.156 & 0.220 & 0.002 \\
\hline Manali & 0.019 & 0.02 & 0.02 & 6.51 & 6.09 & 6.22 & 0.000 & 0.000 & 0.000 & 0.566 & 0.529 & 0.539 \\
\hline Shimla & 0.011 & 0.01 & 0.02 & -0.02 & -0.53 & 0.46 & 0.982 & 0.602 & 0.650 & 0.000 & 0.009 & 0.007 \\
\hline Palampur & 0.021 & 0.02 & 0.03 & 1.48 & -0.67 & 0.05 & 0.135 & 0.485 & 0.956 & 0.120 & 0.028 & 0.000 \\
\hline Solan & 0.020 & 0.03 & 0.02 & 1.27 & 0.67 & 1.96 & 0.199 & 0.490 & 0.052 & 0.063 & 0.019 & 0.138 \\
\hline Ranichauri & 0.016 & 0.02 & 0.02 & -2.10 & -2.00 & -1.77 & 0.037 & 0.047 & 0.077 & 0.137 & 0.125 & 0.101 \\
\hline Jammu & 0.019 & 0.02 & 0.02 & 1.91 & 2.62 & -0.94 & 0.067 & 0.014 & 0.358 & & 0.209 & 0.033 \\
\hline Chandigarh & 0.010 & 0.01 & 0.01 & 2.29 & 3.05 & -0.19 & 0.029 & 0.005 & 0.848 & 0.144 & 0.231 & 0.001 \\
\hline Ambala & 0.009 & 0.01 & 0.01 & 1.37 & 1.31 & 0.94 & 0.181 & 0.198 & 0.352 & 0.051 & 0.047 & 0.025 \\
\hline Saharanpur & & 0.05 & 0.09 & 0.41 & -0.04 & 1.01 & & 0.970 & 0.288 & 0.020 & 0.000 & 0.113 \\
\hline Delhi & 0.010 & 0.01 & 0.01 & 1.35 & 1.90 & -0.37 & 0.189 & 0.067 & 0.711 & 0.059 & 0.111 & 0.005 \\
\hline Karnal & 0.005 & 0.01 & 0.01 & 2.66 & 2.75 & 1.33 & 0.011 & 0.009 & 0.192 & 0.148 & 0.156 & 0.041 \\
\hline Patiala & & 0.01 & 0.01 & 1.63 & 1.09 & 1.85 & & 0.284 & 0.074 & & 0.039 & 0.106 \\
\hline Ludhiana & 0.009 & 0.01 & 0.02 & 5.16 & 7.05 & 2.83 & 0.000 & 0.000 & 0.008 & 0.497 & 0.648 & 0.229 \\
\hline Rohtak & 0.010 & 0.01 & 0.01 & 1.57 & 1.13 & 2.33 & 0.125 & 0.263 & 0.025 & 0.059 & 0.032 & 0.122 \\
\hline Bathinda & 0.012 & 0.02 & 0.02 & -0.02 & 1.12 & 2.06 & 0.982 & 0.257 & 0.041 & 0.000 & 0.043 & 0.132 \\
\hline Hisar & 0.007 & 0.01 & 0.01 & 1.86 & 1.70 & 1.46 & 0.069 & 0.097 & 0.151 & 0.075 & 0.063 & 0.047 \\
\hline Sirsa & 0.017 & 0.02 & 0.02 & 3.96 & 3.75 & 2.99 & 0.000 & 0.001 & 0.004 & 0.359 & 0.335 & 0.242 \\
\hline Bawal & 0.013 & 0.01 & 0.02 & 1.99 & 1.91 & 1.54 & 0.055 & 0.065 & 0.133 & 0.117 & 0.109 & 0.074 \\
\hline Narnaul & 0.010 & 0.01 & 0.01 & 0.76 & 0.76 & 0.39 & 0.443 & 0.440 & 0.690 & 0.016 & 0.016 & 0.004 \\
\hline Ganganagar & 0.010 & 0.01 & 0.01 & 2.27 & 2.42 & 0.66 & 0.030 & 0.021 & 0.517 & 0.142 & 0.159 & 0.014 \\
\hline Jaipur & 0.012 & 0.01 & 0.01 & 2.33 & 2.62 & 0.88 & 0.026 & 0.013 & 0.387 & 0.141 & 0.173 & 0.023 \\
\hline Hills & 0.017 & 0.02 & 0.02 & 0.81 & 0.13 & 1.11 & 0.230 & 0.272 & 0.422 & 0.148 & 0.080 & 0.155 \\
\hline Plains & 0.014 & 0.01 & 0.02 & 1.97 & 2.17 & 1.17 & 0.186 & 0.179 & 0.299 & 0.230 & 0.349 & 0.045 \\
\hline NW India & 0.015 & 0.02 & 0.02 & 1.65 & 1.63 & 1.16 & 0.198 & 0.197 & 0.332 & 0.238 & 0.317 & 0.091 \\
\hline
\end{tabular}


Fig.1 Shift in maximum \& minimum temperatures at hills and plains in D3 (2005-2014) over D1 (1985-94)
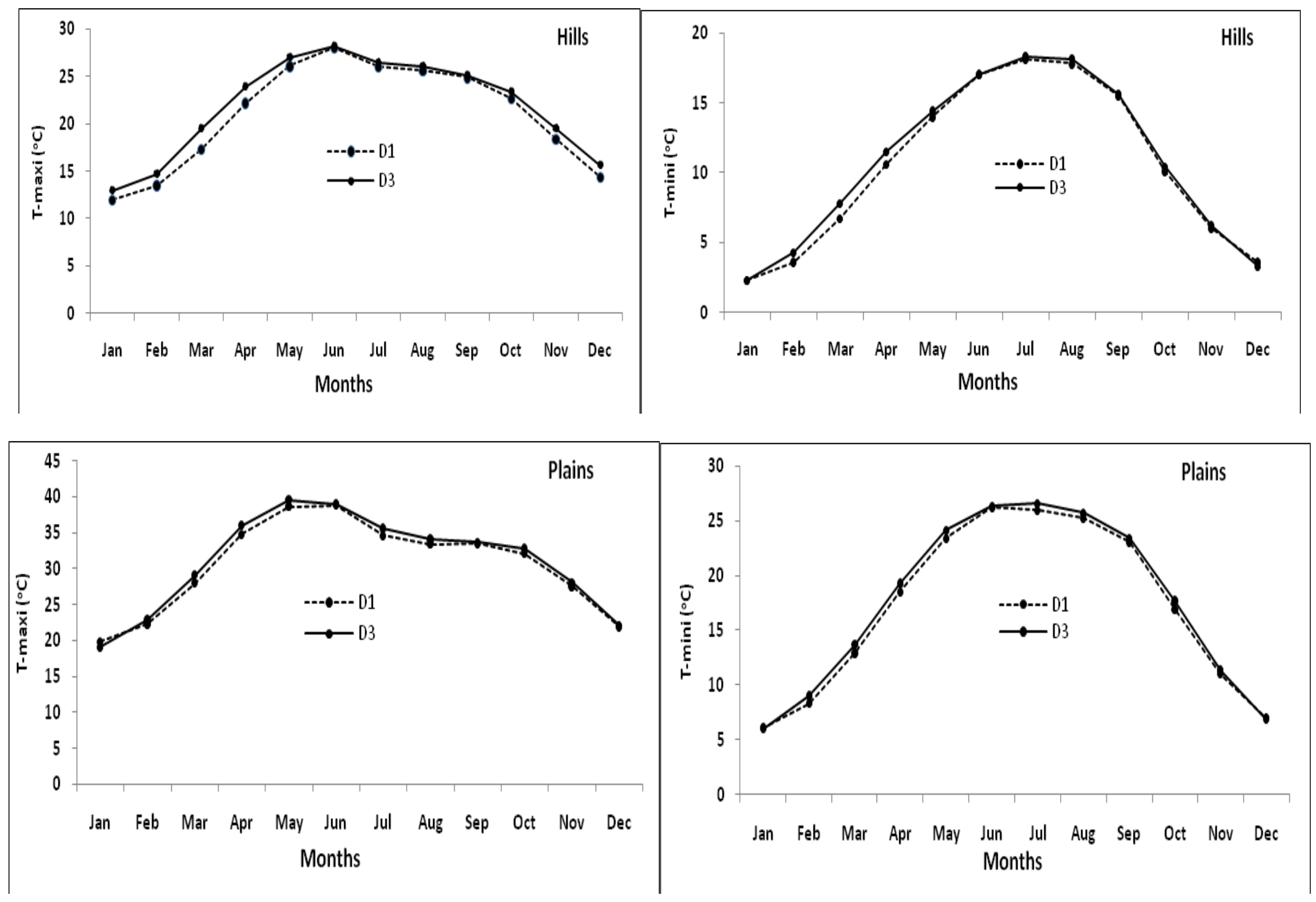
Map.2 Spatial distribution of maximum temperature during effective growing season. Map.3 Spatial distribution of maximum temperature during dormant season
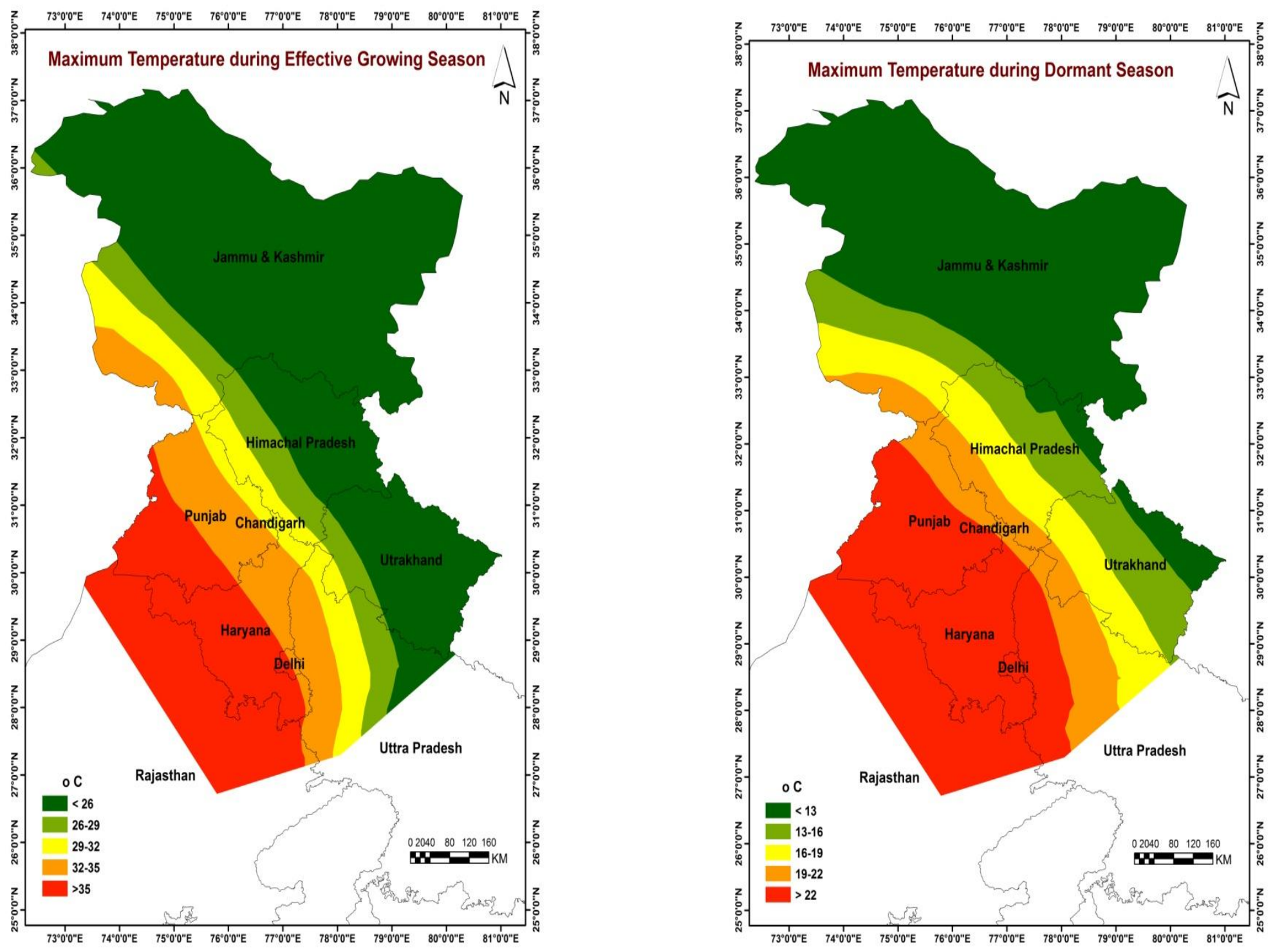
Map.4 Spatial distribution of minimum temperature during effective growing season. Map.5 Spatial distribution of minimum temperature during dormant season
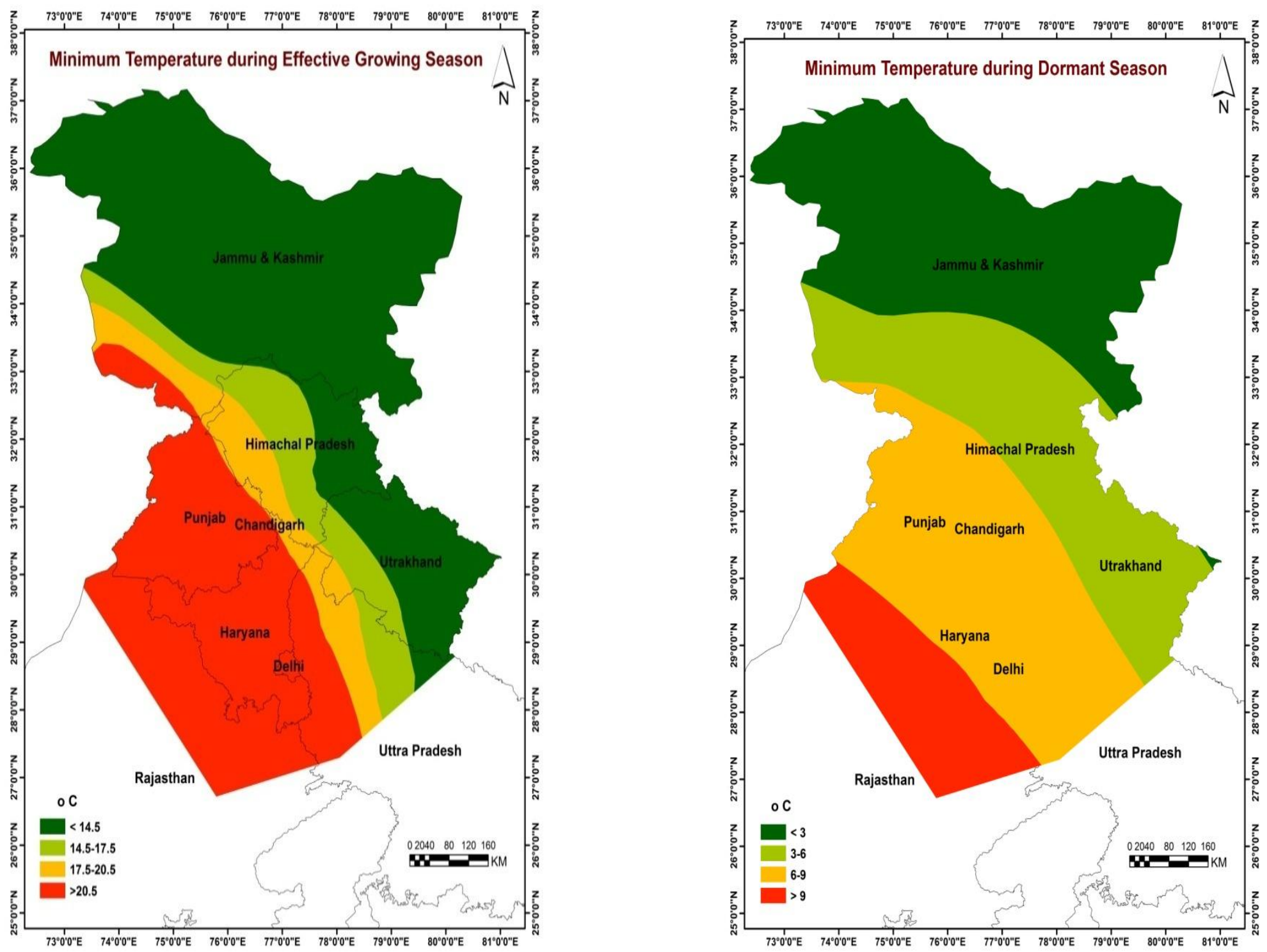
Map.1 Location of the study area

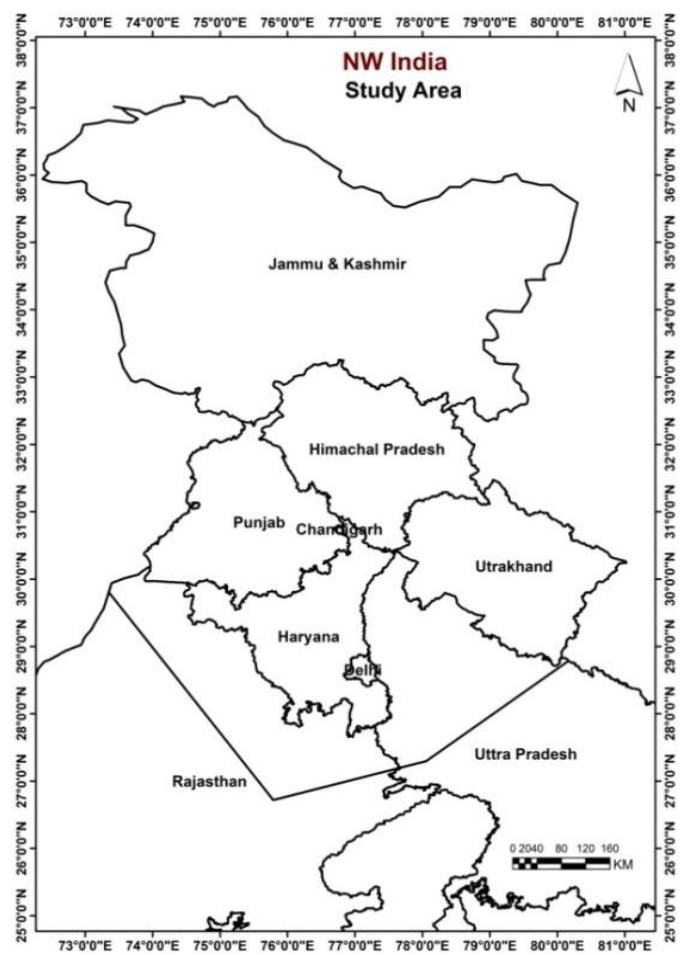

\section{Shift in decadal temperatures}

At hills no shifts in the month of occurrence of peak average maximum and minimum temperatures were observed during the present time scale (D3) compared to previous one (D1) and similar trend was observed at plains (Fig. 1). Average maximum and minimum temperatures of March-April during the present time scale was significantly higher than the average maximum and minimum temperature during its previous time scale at both hills and plains. Same is the case with average maximum temperature of January, February, May, November and December at hills, average minimum temperature at hills, average maximum temperature of May, July, August at plains and average minimum temperature of all the months except January, June and December at plains (Fig. 1). These shifts in temperature are in the conformity of the perception of farmers in western Himalayas (Vedwan and Rhoades, 2001).

\section{Temperature zones}

The temperature constraints in crop ecological zoning are related to the length of the temperature growing period, i.e. number of days with a mean daily temperature above $5^{\circ} \mathrm{C}$. Spatial variation in temperature (maximum and minimum) is depicted in Maps 2-5. During effective growing season north-west India was divided into five zones based on maximum temperature $\left(<26^{\circ} \mathrm{C}, 26-\right.$ $29^{\circ} \mathrm{C}, 29-32^{\circ} \mathrm{C}, 32-35$ and $>35^{\circ} \mathrm{C}$ ) and four zones based on minimum temperature $\left(<14.5^{\circ} \mathrm{C}, 14.5-17.5^{\circ} \mathrm{C}, 17.5-20.5^{\circ} \mathrm{C},>20.5^{\circ} \mathrm{C}\right)$ taking a class interval of $3^{\circ} \mathrm{C}$. The normal maximum temperature during effective growing season ranged from $25.6^{\circ} \mathrm{C}$ to $36.4^{\circ} \mathrm{C}$ and minimum temperature from $11.5^{\circ} \mathrm{C}$ to $22.3^{\circ} \mathrm{C}$, showing an increasing trend from north-east to south-west (Map 2\& 4).

Similarly during dormant season north-west India was divided into five zones based on 
maximum temperature $\left(<13^{\circ} \mathrm{C}, 13-16^{\circ} \mathrm{C}, 16\right.$ $19^{\circ} \mathrm{C}, 19-22^{\circ} \mathrm{C}$ and $>22^{\circ} \mathrm{C}$ ) and four zones based on minimum temperature $\left(<3{ }^{\circ} \mathrm{C}, 3-6^{\circ} \mathrm{C}\right.$, $6-9^{\circ} \mathrm{C},>9^{\circ} \mathrm{C}$ ) taking a class interval of $3^{\circ} \mathrm{C}$. The normal maximum temperature during dormant season ranged from $10.8^{\circ} \mathrm{C}$ to $24.1^{\circ} \mathrm{C}$ and minimum temperature from $0.01{ }^{\circ} \mathrm{C}$ to $9.8^{\circ} \mathrm{C}$, showing an increasing trend from north-east to south-west (Map $3 \& 5$ ). This might be because of topography relief, which increased from SW to NE of study area. Similar results also repotted by IPCC (2014); Singh et al., (2010) and Gautam et al., (2014).

Normal annual maximum temperature was increasing $3.0^{\circ} \mathrm{C} / 100$ years, $0.1^{\circ} \mathrm{C} / 100$ years and $0.9^{\circ} \mathrm{C}$ per 100 years and minimum temperature was increasing at the rate of $1.6^{\circ} \mathrm{C} / 100$ years, $1.5^{\circ} \mathrm{C} / 100$ and $1.6^{\circ} \mathrm{C}$ per 100years for hills, plains and north-west India, respectively.

The normal seasonal maximum temperature during effective growing season was increasing with the rate of $2.1^{\circ} \mathrm{C} / 100$ years, $0.4^{\circ} \mathrm{C} / 100$ years and $0.9^{\circ} \mathrm{C} / 100$ years minimum temperature at the rate of $1.2^{\circ} \mathrm{C} / 100$ years, $2.0^{\circ} \mathrm{C} / 100$ years and $1.8^{\circ} \mathrm{C} / 100$ years in hills, plains and north-west India, respectively.

During dormant season the normal seasonal maximum temperature was showing a decreasing trend of $2^{\circ} \mathrm{C} / 100$ year in plains, $0.3^{\circ} \mathrm{C} / 100 y e a r s$ in north-west India but an increasing trend of $4.4{ }^{\circ} \mathrm{C}$ per 100years in hills but, minimum temperature for was increasing with the rate of 2/100years, 0.8/100year and $1.22^{\circ} \mathrm{C} / 100$ year in hills, plains and north-west India, respectively.

No shifts in the month of occurrence of peak average maximum and minimum temperatures were observed. North-west India was divided into six and seven zones based on spatial distribution of annual maximum and minimum temperatures and into five and four zones during effective growing and dormant seasons.

\section{References}

Akbar, P. I., Kanwar, M. S., Saleem, M. M. and Hussain, A. 2013. Protected Vegetable Cultivation Technology for Cold Arid Agro-ecosystem of Ladakh, International Journal of Horticulture, 1.3 (19):109-113.

Bandyopadhay, A., Bhadra, A., Raghuwanshi, N. and Singh, R. 2009. Temporal trends in estimates of reference evapotranspiration over India. $J$. Hydrol. Eng., 14(5): 508-515.

Bawa, K.S., Koh, L.P., Lee, T. M., Liu, J., Ramakrishna, P.S., Yu, D.W., Zhang, Y. and Raven, P.H. 2010. China, India and the environment.Science, 327:14571459.

De Jager, J. M. and Schuize, R. E. 1977. The broad geographic distribution in Natal of Climatological factors important to agricultural planning. Agrochemophysica., 9: 81-91.

Du, M.Y., Kawashima, S., Yonemura, S., Zhang, X.Z. and Chen, S.B. 2004. Mutual influence between human activities and climate change in the Tibetan plateau during recent years. Global and Planetary Change, 41:241249.

Gautam, H. R., Sharma, I. M. and Kumar, R. 2014. Climate change is affecting apple cultivation in Himachal Pradesh, Current Science, 106 (4): 498-499.

IPCC 2001. The IPCC third assessment report, Cambridge University Press, Climate Change vols.I (the scientific basis) II (Impacts, adaptation and vulnerability).

IPCC 2007. Climate change: The physical science basis. Contribution of working group I to the fourth assessment report 
of the intergovernmental panel on climate change. Cambridge: Cambridge University Press. 2. Xiong W, Lin E, Ju, $\mathrm{H}$., $\mathrm{Xu}$ Y. Climate change and critical

IPCC, 2014. Climate change 2014: Impacts, adaptation, and vulnerability. Working Group II contribution to the IPCC Fifth Assessment Report. Cambridge, United Kingdom: Cambridge University Press. www.ipcc.ch/report/ar5/wg2.

Jain, S. K and Kumar, V. 2012. Trend analysis of rainfall and temperature data for India. Current Science, 102: 37-49

Jangra, S and Singh, M. 2011. Analysis of rainfall and temperatures for climatic trend in Kullu valley. Mausam, 62 (1): 77-84.

Kaur, P. and Hundal, S. S. 2006. Effect of possible futuristic climate change scenarios on productivity of some kharif and rabi crops in the Central Agroclimatic Zone of Punjab. Journal of Agricultural Physics, 6: 21-27.

Kumar, P. V., Rao, V. U. M., Bhavani, O., Prasad, R., Singh, R. K. and Venkanteswarlu, B. 2015. Climate change and variability in midHimalayan region of India. Mausam, 66(2): 167-180

Negi, G. C. S., Samal, P. K., Kuniyal, J. C., Kothyari, B. P., Sharma, R. K. and Dhayani, P. P. 2012. Trop. Ecol., 53(3): 345-356.

Pathak, B., Kalita, G., Bhuyan, K., Bhuyan, P. K. and Moorthy, K. K. 2010. Aerosol temporal characterstics and its impact on shortwave radiative forcing at a location in the northeast of India. $J$. Geophysical Res., 115, D10204, doi:10.1029/2009JD013462

PTI (Press Trust of India). 2015. $4^{\circ} \mathrm{C}$ rise in global temperature to hit daytime outings in North. The Tribune, July 20, 2015 page 7 .

Sharestha, U. B., Gautam, S. and Bawa, K. S. 2012. Wide spread climate change in the Himalayans and associated changes in local ecosystems, PLoS ONE, 7, e36741, doi:10.1371/journal.Pone.0036 741

Sharma, E., Chetri, N., Tse-ring, K., Shrestha, A. B., Jing, F., Mool, P. and Eriksson, M. 2009. Climate change impacts and vulnerability in the eastern Himalayas. ICIMOD, Kathmandu, Nepal

Singh, S. P., Singh, V. and Skutsch, M. 2010. Climate Dev.,2: 1-13

Vedwan, N. and Rhoades, R. E. 2001. Climate change in the Western Himalayas of India: A study of local perception and response. Climate Research, 19: 109-117.

Vinod, K. 2015. Agro-ecological zoning of Haryana in context of climate change and agricultural post-harvest avenues. Thesis submitted to the Chaudhary Charan Singh Haryana Agricultural University, Hisar

Xu, J., Grubine, R. E., Shrestha, A., Eriksson, M., Yang, X., Wang, Y. and Wilkes, A. 2009. The melting Himalayas: Cascading effects of climate change on water, biodiversity and livelihoods. Conservation Biology, 23: 520-530.

\section{How to cite this article:}

Mohan Singh, Ram Niwas, M.L. Khichar and Godara, A.K. 2018. Zoning and Trend Analysis of Temperatures for Fruit Crops in North-West India Using GIS. Int.J.Curr.Microbiol.App.Sci. 7(01): 2970-2985. doi: https://doi.org/10.20546/ijcmas.2018.701.355 